\title{
ON THE IMPORTANCE OF WOLVES
}

\author{
KEVIN LEWIS O'NEILL \\ University of Toronto \\ (D) http: / / orcid.org/0000-0001-6880-9146
}

The wolf will live with the lamb, the leopard will lie down with the goat, the calf and the lion and the yearling together; and a little child will lead them.

His speech was ecstatic. Floridly psychotic, with hallucinations of Jesus, a young man turned to me to say: "I am the beast of the apocalypse." 1 And he was not alone. While the symptoms of mental disorder are often subtle, discernible only by a clinician, others are obvious even to the anthropologist. One young man huddled in a corner; another mumbled incoherently as he paced the floor; a third masturbated himself through his pants. A half dozen more men with similarly observable signs sat nearby. "They are wolves [lobos]," the pastor said. "Their families brought them here." By "here," the pastor meant one of Guatemala City's Pentecostal drug rehabilitation centers. These are onetime factories, garages, and apartment buildings that have been renovated for rehabilitation with razor wire, steel bars, and iron gates. They keep pace with the country's growing rapprochement with illicit drugs by holding drug users (often against their will) for months, sometimes for years. These centers also warehouse the mentally ill. 
"A wolf is a crazy person," the pastor said while trying to define the term. "A wolf is someone who doesn't listen. Someone who you can't control and who can't even control himself." Insisting on the incorrigibility of these creatures, the pastor then turned toward more pastoral terrain. "And these wolves are so valuable [valiosos]," he said. "They are so much more valuable than the sheep."

It is this Pentecostal appreciation of wolves that the present essay explores, assessing not only the theological anthropologies that make such an appraisal possible but also the pastoral power that it produces. For the wolf has never gotten its full due. Thomas Hobbes (1998, 3), of course, builds his theory of state power from the premise that "man is wolf to man [homo homini lupus est]," while debates about the unconscious (Freud 1996), the sovereign (Derrida 2009), and the wolf pack (Hardt and Negri 2000) imagine this animal as a model for human sociality (see also Torrano 2016). Yet anthropologists have never taken much interest in this boundary creature. Instead, biopolitical imaginaries (Redfield 2012), with their pastoral fantasies (Rose 2007), tend to fixate on shepherds and their sheep, even to the point of understanding modern governance as a matter of the sheepfold (Foucault 2007, 172). This is one reason why anthropologists have engaged (with near equal interest) humanitarian projects that make live (Bornstein 2012; Fassin 2012; Malkki 2015) and zones of social abandonment that let die (Biehl 2005; Li 2010; Allison 2013). The problem is that none of this work appreciates the wolf in any significant way, too quickly overlooking the pastoral importance of irredeemable figures. Giorgio Agamben $(1998,63)$ even goes so far as to banish the wolf to the edge of the city, to the very lip of the forest - "to dwell paradoxically within both while belonging to neither."

Pentecostals know better. "I can't care for [the sheep] without the wolves," the pastor admitted. For he knew, as do most cultural critics, that wolves are exceedingly important, not least because they provide the conditions through which a Christian humanity might assert itself (see Cohen 2012). The wolf, in fact, has long delimited the morality through which bodies and souls may move, and it has done so with such success in Guatemala City that pastors across the capital acquire rather than abandon them. The faithful actively seek these wolves out, often going to great lengths to bring them into the fold. "I look for wolves," the pastor told me. "I search all over the city for them." It is, in the end, the importance of these wolves that provokes a guiding question. Put in ethnographic terms, it would be something like: how does this transformation — of status, value, and maybe even species - make the mentally ill in Guatemala City absolutely essential to the flock, with the invention and domestication of wolves not only 
justifying captivity but also contributing to the management of populations? Or, to put the question in slightly more pastoral terms, what would it mean for governance to be a matter of wolves rather than sheep?

\section{MADNESS}

An answer to these questions begins with the state of mental health in Guatemala. With only 1 percent of the country's health-care budget addressing matters of mental illness (WHO 2011), Guatemala's only psychiatric institution is in a state of crisis, with one journalist going so far as to name this institution "the world's most dangerous hospital" (Rogers 2014). With rampant reports of patient abuse, which includes the sexual assault of heavily sedated minors, the hospital diagnoses and discharges patients as quickly as possible, in the guise of deinstitutionalization but really to shift the burden of care from the state to the family. The hospital also flatly refuses to admit anyone addicted to drugs. This is a brutal policy — not only because mental illness and substance abuse are notoriously difficult to disentangle but also because access to habit-forming drugs has expanded throughout the region.

In 2004, 10 percent of the cocaine produced in the Andes and bound for the United States passed through Guatemala (UNODC 2012). More than ten years later, after a shift in U.S. interdiction efforts, some 80 percent of this product touched Guatemalan soil (Fielding and Giacomello 2013). One effect of this shift has been a spike in the use of crack cocaine. Drug-trafficking countries, the literature notes, often become drug-consuming countries (Gootenberg 2008). A second effect, inseparable from the first, has been the proliferation of Pentecostal drug rehabilitation centers. These are for-profit enterprises that self-consciously capitalize on the country's growing dependency on not just crack cocaine but also new forms of Christianity. Once overwhelmingly Roman Catholic, Guatemala today is at least 50 percent Pentecostal and Charismatic Christian (GarrardBurnett 2015; see also Pew Forum on Religion and Public Life 2006). ${ }^{3}$

Pentecostalism has since emboldened a particularly entrepreneurial set of pastors to sell something called theological therapy (teoterapia). It comprises a mashup of Pentecostal theology, twelve-step programming, and self-help psychology. Its guiding assumption is that captivity will give way to conversion. It rarely does. Yet this bald fact has done nothing to slow the growth of these centers, for a simple reason: these centers provide a practical solution to a concrete problem. Drug use is up, state resources are down, and Pentecostalism is the discourse of change. The net result is a shadow carceral system infused with 
Pentecostal imperatives not just about heaven and hell, but also about who can be held captive and why. This theological construction carries considerable consequences. Today more Guatemalans find themselves tied up inside these centers than locked up inside of maximum-security prisons. ${ }^{4}$

A growing number of these captives (internos) have clinical diagnoses from the state's psychiatric hospital as well as open-ended prescriptions for antipsychotic medications. Once discharged as outpatients, the mentally ill often enter Pentecostal drug rehabilitation centers - largely because families are desperate for affordable long-term care. State social workers also facilitate this public-to-private transfer by providing these families with a list of pastors eager to engage the mentally ill. The only hitch is that the families must understand that the centers do not address matters of sanity or sickness so much as sin and salvation. Diagnostic tests and patient files do not structure these centers so much as a cluster of Christian coordinates: salvation is real, hell is eternal, and Jesus loves you. Matching the mentally ill to this message often means shoehorning them into a moral biography that posits an exceedingly sinful prehistory. "They did it to themselves," the pastor told me. "Drugs turned all of these guys into wolves. Sin transformed them forever." As specious as this story is disturbing, such moral retrofitting is nonetheless nonnegotiable. "We only deal with wolves," the pastor insisted, and so wolves are what he gets.

\section{LYCANTHROPY}

This Pentecostal preoccupation with wolves can seem positively medieval at times, not least because humans transforming into wolves constituted a fundamental theological problem in the Middle Ages (Bynum 2001). Biblical and classical writings raised the phenomenon with such frequency that Augustine (1950, 624), Ambrose (Nazianzen and Ambrose 1953, 256-58), and Aquinas (2002, 1024) routinely found themselves knee deep in Neoplatonic debates over the meaning and possibilities of the human body. Likely triggered by adjacent conversations over transubstantiation, the equally confounding claim that bread and wine can become flesh and blood, these theological reflections opened up into matters of Christian ontology. For if rods could become serpents (Exodus 7-8) and water could become wine (John 2:1-11), then why could men not become wolves? Augustine, for one, was quick to concede that the monstrous and the grotesque, meaning the deformed and the disabled, could certainly embody the divine image of God, even if their relative humanity remained unclear. Yet he opposed with equal force the idea that humans could transform into 
wolves. The devil, he argued, can create no new nature, and so all reports of humans changing into animals were illusions. Augustine was absolutely clear about this last point.

The problem was that no one seemed to care. Medieval literature routinely depicts werewolves as sympathetic protagonists in ways that piqued theological interest — not so much in demonic activity as in the constitution of interior human consciousness as bodies came to resemble wolves (Otten 2002). Yet throughout this literature there appears a continuous resistance to stories of complete transformation, with the eyes of the wolf maintaining their original human form (Shyovitz 2014, 526). Rarely treating the matter metaphorically or even as literary motif, several twelfth-century theologians posit that becoming a wolf involves internal continuity alongside external transformation. The body changes, but the soul stays the same. This contrast between experience and appearance is one reason why the subjects of these stories can seem so very sympathetic. Each of these animals desperately wants to be otherwise. Often bearing little resemblance to the ravenous wolf of Genesis 49:27 or to the savage wolf of Acts 20:29, these poor souls find themselves literally trapped by their transformation, completely incapable of escaping their own corporeality. They haunt cemeteries and howl at the moon not because of monstrous appetites, but rather because of a cruel melancholy brought on by the horrifying condition of being completely civilized and yet looking like a dog.

Melancholy followed these tales of transformation as the phenomenon pivoted from the realm of theology to that of pathology. From the sixteenth century onward, even up into the mid-twentieth century, the medical sciences published case studies that describe the afflicted symptomatically_-with pale skin, yellow teeth, and tufts of unruly hair (Jackson 1978). Eyewitness reports also confirm that the tormented loped about graveyards, alone and at night (Coll, O'Sullivan, and Browne 1985). These moments of documentation emerged alongside the human sciences in an effort to corral superstition into schizophrenia (Keck et al. 1988). They largely succeeded. One thousand years after Ambrose echoed Augustine to argue that all demonic transformations are illusions, psychologists mirrored theologians only at the level of earnestness. In 1850, one wrote that lycanthropy "is an expression of a bestialization of character, which is channeled into the corresponding behavior pattern of a wild animal" (Metzger 2013, 352). Here, the psychosocial language of patterned behaviors tames a titillating conversation about shape shifting and boundary transgression, ultimately establishing with sci- 
entific precision that human beings cannot turn into wolves. Psychologists have been absolutely clear about this, too.

\section{TRAPPED}

The problem is that Pentecostals do not seem to care. "Sinners become wolves all the time," the pastor told me as we walked up a narrow set of stairs. They led to the roof of his center. A two-story building located in the middle of the city, just blocks from the national palace, the center holds as many as seventy drug users on the first and second floors. Originally built in the 1980s as a hotel for Central American businesspeople, the structure soon sat empty. The short story is that the country's civil war (1960-1996) sparked waves of rural-to-urban migration that pushed the wealthy from the city center to greener plots of land. The building remained unoccupied for years until the pastor spotted it as a lowrent opportunity. Inverting the logic of private security by aiming to keep drug users in rather than out, the pastor fortified the building. "All I had to do," he told me, "was to put bars on the windows and locks on the doors." His words came to mind as we reached the roof. Passing through one last locked door, stepping out into the midday sun, the pastor announced with no real reverence: "And this is where we keep the wolves." A riot of steel rods crisscrossed over our heads, soldered in just such a way as to form an expansive cage. "I had a friend do the metal work," he said, "so no one can escape."

The sight was surreal, even for the experienced, and increasingly so as the pastor introduced me to his captives. "This is Augustín," the pastor said. "He arrived here five years ago after drinking rubbing alcohol [química] and smoking crack cocaine." Squatting in a corner, Augustín did not respond to us. The pastor then turned to Tomás. "He has been here for ten years," the pastor said. "Tomás turned into a wolf because of massive amounts of marijuana and masturbation.” Tomás blushed as the pastor directed my attention to Manuel. "This is a little more difficult to explain," he admitted, "but Manuel smoked marijuana, and now he believes that angels visit him." The pastor took a moment to consider a more complete explanation, but then he concluded without much context: "And so he feeds the angels mayonnaise." Manuel dripped the condiment onto the end of a stick and then waved it over his head. "He's been here for eight years."

Eight years earlier Manuel lived with his father on the outskirts of Guatemala City. From a very young age, Manuel exhibited signs of mental illness, which included defiant behavior, irregular sleep patterns, and hyperactivity. At first manageable, at least for a middle-aged parent, Manuel's increasingly erratic be- 
havior eventually overwhelmed his aging father. His son began to hear voices, speak to himself, and retreat into his room for days on end. The angels also started to visit him. "He got aggressive with me," Manuel's father said, "and he got aggressive with the neighbors.” One story stands out. When Manuel was nineteen years old, a neighbor accused him of sexually assaulting his ten-year-old daughter. The details are difficult to determine, but what is clear is that the neighbor called the police. Manuel took off running, but they soon found him hiding in a drainage pipe. "The police immediately noticed that Manuel was not right," his father said, "and so they asked me if Manuel used drugs." The father had found marijuana in Manuel's room a year earlier, and he told the police as much. "They then asked me to make a decision," he said. "Either Manuel could stand trial in front of a judge [for sexual assault] or he could enter a [Pentecostal drug rehabilitation] center." Well aware that Guatemala's pretrial detention centers have long been at 500 percent capacity, with due process often taking two years (CIEN 2011), Manuel's father sidestepped the state by choosing a center.

Back on the roof, still under the rods, the pastor described Manuel to me as "trapped" (atrapado). This seemed self-evident, given the cage, but he meant something far more profound than the materiality of his immediate captivity. "Manuel is trapped inside of himself," he told me. "We've lost him forever." The pastor then compared wolves to sheep. "Those drug users [on the first and second floors of the center]," he said, "they can be saved. Sheep, even black sheep [ovejas negras], can accept Jesus Christ as their savior." The pastor then turned toward Manuel. "But the wolves," he said, "they are different." When I pressed him to define this difference, the pastor seemed to approximate Plato $(1961,66)$ in imagining Manuel's body as a prison house for his soul. "You can preach to wolves all you want," the pastor said, "but they won't change." Insisting that the rational ground on which Manuel's soul once stood had since buckled under the weight of his sins, the pastor essentially accused Manuel of being the "first accessory to his own confinement" (Plato 1961, 66). "It's Manuel's fault," the pastor said. "He did it to himself."

Theologically horrifying, with Manuel's soul trapped somewhere inside of his body, this case as narrated by the pastor effectively inverted those werewolf stories of old. Rather than interior continuity and external transformation, Manuel's reported drug use had triggered external continuity and interior transformation. His soul had changed, but his body had stayed the same. The net effect, by the pastor's own admission, was nothing short of an id without its ego-a 
throbbing bundle of animal desires. "It's not just Tomás," the pastor admitted. “They all masturbate."

It was a tragic scene by any standard. Ontologically set apart from the sheep, these wolves ended up inspiring as much sympathy as their medieval counterparts. Everyone involved, from the pastor to the parents, wanted each of them to be otherwise. "But that would take a miracle," the pastor told me, "and I've never seen that happen." So in the absence of a divine intervention, but in the name of God, this pastor held these men captive-for the horrifying condition of looking like a Christian and yet acting like a dog.

\section{ACQUIRED}

This break between body and soul is why the pastor sent so many of these men straight to a psychiatrist. After fishing Manuel from a drainage pipe and then presenting his father with an ultimatum, the police escorted the two men to Guatemala's psychiatric hospital. The pastor met them there, with the doctor diagnosing and discharging Manuel in a matter of hours. The psychiatrist on staff was apparently encouraged by the prospects of Manuel entering a Pentecostal drug rehabilitation center that very same day. "The doctor also knew the pastor," Manuel's father told me, "and the pastor recognized the police officers." His son subsequently left the hospital a schizophrenic and entered the center a wolf, all on the wings of his new prescription for chlorpromazine.

Chlorpromazine is one of the world's most commonly prescribed antipsychotic medications and crucial to the workings of the pastor's center. His wolves take the substance every single day - and not in spite of but rather for the side effects. At the end of Manuel's examination, the psychiatrist mentioned that the drug can cause dizziness, insomnia, weight gain, dry mouth, blurred vision, constipation, swelling of the hands, and a stuffy nose, but the only side effect that seemed to please the pastor made the medication sound like a chemical castration. "The medicine," the pastor said, "causes drowsiness and impotence. It makes it difficult to ejaculate." With souls trapped inside of bodies and bodies acting irrespective of souls, chlorpromazine allowed the pastor to put a pharmaceutical leash on these men. "The medication," the pastor said, "makes the wolves so much easier to manage."

Chlorpromazine's availability in Guatemala largely depends on a government initiative that provides the chronically ill with medications at no cost (Anson et al. 2012). Becoming law soon after the 1996 Peace Accords, in the spirit of equality and accessibility, Guatemala's Ministry of Health established a basic list 
of medicines for common diseases affecting the general population. The ministry also began negotiating with pharmaceutical companies to identify suppliers and set prices, with the government eventually stocking and subsidizing more than five hundred outlets across the country. Although tethered to an erratic healthcare budget, itself hitched to one of the most precarious tax bases in all the Americas (Sridhar 2007), the program supplies a small subset of the country with free medication while providing everyone else with a viable alternative to the free market. Consisting of an intricate web of for-profit pharmacies, the private sector routinely gouges customers by charging them anywhere between ten to twentythree times the recommended international price for such essential medicines as chlorpromazine.

"These wolves wouldn't be here without chlorpromazine," the pastor said. He then quickly conceded that "the center wouldn't be here without these wolves." The pastor then compared wolves to sheep one more time. "Sheep come and go," he said. "Someone who smokes crack can be here for a week or a month, but then he's gone." In an effort to shepherd his herd, to stabilize his flock, the pastor negotiates with families for contractually obligated lengths of captivity, be it for one, three, or six months, but the center's population is in constant motion. "We can hold about seventy guys here at a time," the pastor said, "but sometimes we only have twenty." This swing is significant, especially given the center's fee-for-service model. Stretches of uneven income have been known to shutter centers, with pastors unable to adjust to rapidly differentiating levels of revenue.

"This is why the wolves are so important," the pastor explained. "They pay the bills." By this he meant that the family of an average captive pays the pastor roughly US\$100 a month, which makes the monthly difference between a full center (i.e., seventy captives) and a near empty center (i.e., twenty captives) about $\$ 5,000$. With the average annual income in Guatemala hovering around $\$ 2,700$, this is a huge amount of money and would prove precarious to any operation were it not for the fact that the families of wolves pay more than twice than the families of sheep - and not for one, three, and six months, but rather for five, eight, and ten years. These are the respective lengths of captivity for Augustín, Manuel, and Tomás. Having not just run the numbers but also shouldered some rather lean months, the pastor knows full well that he can pay rent and utilities as long as he has eight wolves on his roof.

The most successful centers follow this business model, keeping a close eye on the deeply interrelated variables of stock (wolves) and flow (sheep). In doing 
so, pastors fundamentally reframe the wolf as essential rather than peripheral to pastoralism, with a state-allocated antipsychotic medication providing a vital linchpin for a lycanthropic theology that essentially inverts the market value of chronically unemployable schizophrenics.

It is no surprise, then, that the psychiatrist who diagnosed Manuel knew the pastor. Nor is it by chance that the pastor recognized those police officers. They actually called the pastor soon after they had arrested Manuel. There is also nothing serendipitous about the fact that the pastor appears on the social workers' list of centers eager to engage the mentally ill. In fact, he appears at the very top of that list. The pastor, after all, did not agree to house Manuel out of Christian compassion alone. He instead carefully sought out Manuel with a kind of tactical grace that Michel de Certeau $(1984,7)$ might have called the "hunter's cunning." "You have to be patient," the pastor said. "You need to find the right kind of wolf, and then you need to act."

Over the years, this predatory pastoralism has included navigating government bureaucracy, establishing intimate rapport with police officers, befriending teams of social workers, and flipping through stacks of patient files - all to find the right kind of wolf. "I could tell right away that Manuel would be a good fit," the pastor said. "He was quiet, and he never hit me." The pastor also predicted that Manuel would be a good candidate for chlorpromazine. "It all worked out," he said. "Manuel got the prescription. He came to the center, and he settled into a routine." The pastor seemed pleased. "You could also tell," he added, "that Manuel would be really good for the sheep."

\section{LOVED}

Drug users occupy the first and second floors of the pastor's center. Held against their will behind locked doors, their principal task is to convince the pastor that they are ready to leave, that they have been saved. Also interested in salvation, the pastor organizes his flock around a tightly orchestrated series of sermons, testimonies, and church services. The pastor is committed to the power of conversion, to the willful decision to live a good Christian life, but it is works, not faith, that he is able to discern (O'Neill 2017a). "I need to see that the person has changed," he said, "I need to see that he looks different." These signs of salvation can include clean clothes, an upright posture, and a positive attitude. "When they come here," the pastor explained, "these guys are dirty. They've been living on the streets. But after their time [here], they have a haircut, clean clothes. They walk confidently." Christian captivity changes them. 
The most visible sign of salvation is voluntary labor. "When they start helping out," the pastor said, "then I know that they've changed.” Effectively rebranding conscripted labor as occupational therapy, the pastor staffs his center with sheep. They clean the floors, wash the clothes, and cook the food-all in the hopes of demonstrating a newfound commitment to Christ, of staging a life that was once lost but is now found. A large part of this piety has to do with the bottom line. The pastor has no paid staff and, thus, relies on Pentecostalism to convert the most menial of tasks into acts of Christian devotion. "I need to know that [these users] have changed," the pastor said. "Otherwise, I won't let them go." Or as one drug user put it: "If you want to get out of here, you need to do the shit work [la mierda].”

Wolves are the source of this center's most coveted shit work-because caring for these captives is often the clearest way to articulate a personal transformation to the pastor. But the work is not easy. "The wolves demand constant attention," the pastor explained, "to keep them clean. To keep them safe. To keep them from touching themselves." Twenty-four hours a day, seven days a week, this unwaged affective labor taxes even the most sincere of sheep as they struggle to care for multiple men with severe mental illnesses. " "It doesn't always work," the pastor admitted to me. "I can send someone to the roof, but he may only last a day." The biggest problem is that the sheep attack the wolves. "No one is allowed to hit the wolves," the pastor insisted, but it happens. Wolves spit, curse, and bite the sheep, which prompts the fold to beat the wolves. And this is precisely the point. The pastor sends his sheep to the roof to master their own emotions through managing these wolves.

This mandate has made the roof a veritable training ground for recovering drug users and, as a result, has revalued a passive population into a set of pedagogical opportunities for pastoral care. "It's an opportunity," Hugo insisted. In his mid-twenties, with short hair and broad shoulders, Hugo had been inside the center for six months. Dragged to the pastor's front door for his use of crack cocaine, Hugo struggled against, but eventually submitted to, life inside the center. This first meant participating in the sermons, testimonies, and church services, but then he began to clean the floors, wash the clothes, and cook the food. He eventually graduated to the roof - to care for three men, including Manuel. "It brings me such joy," Hugo said as he checked to see whether Manuel had soiled himself. This was one of his tasks. The others, he explained, include "giving Manuel his medicine every day, taking him to the bathroom, bathing him, sometimes feeding him, and cleaning up his messes." I asked about the messes. "I have 
to keep him from masturbating," Hugo said, “and when I can't, then I have to clean up the semen [sperma]." Hugo winced.

These messes proved to be the last straw for Hugo. He was generally able to whistle while he worked, but this particular battle between purity and danger (Douglas 1966) dissolved any distinction that he could maintain between frontand backstage behavior (Goffman 1959). "It's gross," he said. "It gets everywhere. On them. On the toilet." Hugo then whispered: "It even gets on me." While Hugo could concede that Christian servitude had become a necessary moment in his journey toward personal salvation, mopping up Manuel's semen had crystallized the homosociality of this relational labor, pivoting him toward the fear that he now crossed the threshold onto homosexual terrain. "The semen is often what makes the sheep beat the wolves," the pastor admitted. "It's a big challenge for them."

The challenge, of course, cuts both ways. For Hugo, there was the seemingly insurmountable task of matching the right affect to undulating waves of offense. Slapped in the face, with semen and feces no less, Hugo consistently turned the other cheek (Matthew 5:39). "It really is a beautiful opportunity," Hugo once told me, completely unprompted. Those who care for the wolves were also constantly afraid of failure, with well-founded fears that even the smallest of infractions could lead to even more months inside the center. "Manuel is very caring and sensitive," Hugo said, "but it's hard to keep his hands occupied." Pressed to perform the Christian virtues of service and humility, but with no formal training on how to do so, most of these caregivers ended up fixating on the most moral of metrics. Hugo, for one, ended up mirroring the pastor's own anxieties about masturbation, which had far less to do with biblical concerns over scarcity (Genesis 38:8-10) than with the inability of these men to comport themselves like God-fearing Christians (Laqueur 2003). And so Manuel's ejaculations became one of the only indices that the pastor used to assess the quality of Hugo's care. "At the end of the day," the pastor mentioned to me, "I ask Hugo how many times Manuel masturbated and that gives me a sense of how the day went."

\section{RELEASED}

Hugo's days with Manuel soon began to spoil. In April 2015, Guatemalan officials arrested nearly two dozen people for customs fraud, with as many as seventy government employees having received kickbacks from importers in exchange for lower taxes. A United Nations-backed anti-impunity commission estimated that the network cleared $\$ 328,000$ per week, with Guatemala's then 
president Otto Pérez Molina and then vice president Roxana Baldetti receiving roughly 40 percent of the proceeds (Lohmuller 2016). Alongside intricately structured money-laundering schemes and the scamming of some six dozen state contracts, the two government leaders pocketed tens of millions of dollars, spending the cash on such vanity items as vacation homes, liposuction surgeries, and shopping sprees in Miami (Perez D. 2016). Pérez Molina even landed a helicopter valued at \$3,500,000 (BBC News 2016). Audacious even by Guatemalan standards, the scandal proved to be a zero-sum game, as the corrupt stole money directly from public funds. Guatemala's Ministry of Health, for one, had been fleeced, with its basic list of medicines for common diseases quickly becoming an untenable social service. The ministry could no longer provide the chronically ill with medication at no cost, and it completely ran out of its supply of chlorpromazine. All the while private pharmacies leapt at the chance to charge customers twentythree rather than ten times the recommended international price for these essential medicines.

As Guatemalan newspapers sharpened their critiques of the former president and vice president, rightfully commenting that both acted like ids without their egos, like wolves feasting on sheep (el lobo sí se comió a las ovejas; Sarti 2015), this national scandal forced Manuel off his meds, with his mood changing almost immediately. Within a week of his last dosage, Manuel's hands began to shake, and he stopped sleeping through the night. Complaining of a stomachache, Manuel paced the roof for hours while compulsively smacking his lips. Hugo followed close behind him, making sure that Manuel never hurt himself or others-because Manuel had never been so unpredictable. One moment he would sit quietly in a corner, completely incapable of dealing with anyone, and then suddenly he would find himself overcome with rage.

Manuel even started a screaming match with one of his angels, but rather than mayonnaise at the end of a stick, he thrust his finger angrily at his invisible enemy. He threatened the angel, called her a whore (puta), and then began to hit himself with such force that he seemed to risk breaking not just his cheekbone but also his hand. Hugo eventually calmed him down, with the kind of shushes usually reserved for colicky babies, but not before Manuel had seriously bruised the right side of his face. As the welt turned from red to blue to green to brown, Hugo obsessed over what the pastor might say. With his own captivity hitched to the quality of Manuel's care, Hugo worried that Manuel's growing number of outbursts threatened his own road to redemption, and so Hugo tried to hide the injury altogether. Whenever the pastor would reach the roof and walk the floor, 
Hugo would position Manuel — and then constantly reposition him — in such a way as to keep the right side of his face out of sight.

The tediousness of this tactic, its outright absurdity, eventually proved impractical as Manuel began to masturbate more often - at night as he paced the roof, but also in broad daylight while everyone watched. At some point, between balancing the optics of Manuel's bruise and the materiality of his messes, Hugo doubled down on saving himself by managing Manuel. "I had to do something," Hugo shrugged after tying up Manuel with a cord of rope. At first Hugo bound Manuel's wrists, but then he wrapped up Manuel's entire upper body, from his shoulders to his stomach. By the end of it all, Manuel looked like he was in some kind of silent movie, as if he could be laid across railroad tracks, but none of this was theater. At wits' end, with a fear for his own future, Hugo fashioned a kind of moral exoskeleton for Manuel, with the improvisation nesting him inside yet another layer of captivity. On top of a roof, inside of a cage, with his soul trapped somewhere inside of his body, Manuel wrestled against ropes that pinned his arms against his sides.

The pastor did not approve. In fact, he was deeply disturbed-not necessarily by how Hugo treated Manuel but rather because Manuel tempted Hugo. All the pastor had ever asked of Manuel was to be the right kind of wolf, and Manuel, off his meds, was no longer that. For Manuel seemed to bait not just himself but also Hugo toward a constellation of bestial desires, with cruelty proving to be the most pernicious. The signs of this sin were never egregious; Hugo never tormented Manuel, but on more than one occasion, Hugo did seem to enjoy the thrill of this little hunt, with an abundance of affect always surfacing in those moments when Hugo hogtied Manuel. For he did smile every time he approached Manuel with the rope, sometimes even playing with his prey until he had Manuel cornered and then cuffed. Hugo even started to treat the binding of Manuel as some kind of public performance for all the other wolves to watch. "You can see [the sin] in his eyes," the pastor once told me as we also watched Hugo wrap up Manuel.

With Manuel now too wolfish for the center's own good, the pastor decided that Manuel could no longer contribute to the flock, which is why the pastor did not discipline Hugo for abusing Manuel but instead punished Manuel for tempting Hugo. The penance was brisk. After eight years of captivity, on top of that roof and inside of that cage, the pastor ordered Hugo to untie Manuel, walk him down that narrow set of stairs, and then wait for the pastor inside his front office. 
Moments later, for nothing short of looking like a Christian and yet acting too much like a dog, the pastor opened the front door and let Manuel go.

Just like that.

\section{LEVERAGED}

Manuel's father quickly collected him from the streets and immediately brought him home. Some eight years after the suspected assault, with the affected family now living on the other side of the city, Manuel quietly returned to his neighborhood, boldly refusing to enter another center or even engage Guatemala's psychiatric hospital. His father acquiesced, ultimately wanting his son to live with him rather than with another pastor. As of this writing, Manuel spends most of his days standing outside his father's house with a transistor radio hanging from his neck. Quietly perched at the end of a sleepy two-lane road, Manuel feeds his angels mayonnaise for hours on end, and no one seems to care. Off the roof and outside of the center, beyond the reach of the pastor and his daily dose of chlorpromazine, Manuel is no longer a wolf. And like so many stories of old, from the Middle Ages onward, Manuel has returned to his original form only to endure the indifference of being human (Cohen 2012).

The pastor, however, knew that he had a problem on his hands. Augustín and Tomás held form without their daily dosage of chlorpromazine, but the pastor's loss of Manuel immediately put the center at financial risk. With one too few wolves on top of his roof, the entire operation found itself far too leveraged on flow (sheep) rather than stock (wolves), with the former much more unpredictable than the latter. "Sheep come and go," the pastor reminded me. This is why the pastor immediately went to work - navigating government bureaucracy, drawing on his rapport with police officers, reconnecting with teams of social workers, and flipping through stacks of patient files. "I need another wolf," he said with no small amount of trepidation in his voice. For these wolves are the very subjects that allow him to save so many of those sheep-first, by underwriting his center with above-market rates for extended stretches of captivity and, second, by providing pedagogical opportunities for recovering drug users to perform their piety. In no uncertain terms, this center could not continue to exist without at least one more wolf.

And neither could Guatemala. For wolves do not just leverage this pastor's center but all centers in Guatemala City, with these captives allowing some two hundred Pentecostal drug rehabilitation centers to pay the bills. Of added interest is that these wolves, by way of these centers, also backstop the country's prisons 
and psychiatric hospital. Wolves make these institutions viable social services by allowing the state to stash (at no cost to itself) not just hundreds of wolves but also thousands of sheep across an absolutely unregulated industry. With less than 1 percent of Guatemala's prison population having been convicted on drug charges (Fontes, O’Neill, and Giacomello, n.d.) and the country's only psychiatric institution understanding drug use as well beyond the scope of its mission, these centers have become not just sites of extrajudicial incarceration but also Guatemala's largest mental health provider. ${ }^{10}$ The Pentecostal possibility of becoming wolf makes this symbiosis possible, with Christians not just responding to the war on drugs with a complicated mix of compassion and cruelty but also propagating the war itself, albeit on their own ontological terms. Thus an eminently fair, deeply ethnographic question becomes: where would Guatemala be - as a state, as a government, even as a biopolitical entity — without the Pentecostal threat of masturbating wolves?

Any effort at answering this question belies the fact that while Guatemala finds itself overleveraged when it comes to wolves, anthropologists have failed to invest enough time to consider the importance of supposedly incorrigible creatures. There is, of course, a vibrant tradition that understands subjects such as Manuel as victims of precarity (Allison 2013), exposure (Petryna 2002), and abandonment (Povinelli 2011), of a life "unworthy of being lived" (Agamben 1998, 136) and eventually a death “without grief” (Butler 2009, 14-15) or “weeping” (Scheper-Hughes 1989). From this critical perspective, Manuel's expulsion (see Sassen 2014) could easily be read as yet another moment of brutality and complexity in the global economy, and yet there has been very little anthropological reflection on the importance of wolves to pastoralism, beyond rather binomial provocations to focus on the good rather than the bad (Robbins 2013). While Manuel's release might mark the limits of pastoralism with a veritable moment of a wolf in sheep's clothing, the pastor's follow-up work with police, psychiatrists, and social workers maps more closely onto calls to consider the social value of the abandoned (Biehl 2005) or the "suffering subject" (Robbins 2013). The hiccup of adrenaline that followed the pastor's first viable lead, a simple phone call from a friendly psychiatrist, suggests that anthropologists of neoliberalism, precarity, and suffering have been too quick to concede that "man is wolf to man" when it is the wolf that sometimes sets the very conditions for being human. 


\section{ABSTRACT}

What would it mean for pastoralism to be a matter of wolves rather than sheep? Across Guatemala City, Pentecostal drug rehabilitation centers provide one possible answer. These are onetime factories and apartment buildings that have been renovated for rehabilitation with razor wire and steel bars. Largely unregulated, these centers keep pace with Guatemala's growing rapprochement with illicit drugs by holding drug users (often against their will) for months, sometimes for years. They also warehouse the mentally ill, whom the faithful call wolves (lobos). While Pentecostals understand these wolves as incapable of governing themselves, a mix of faith and pharmaceuticals has made this otherwise surplus population central to the management of populations. Providing a provocative counterexample to celebrated ethnographies that tell terrible tales of societies that let die rather than make live, this essay details how and to what effect pastors actively acquire rather than abandon these socalled wolves. [Pentecostalism; pastoralism; captivity; pharmaceuticals; mental illness; Guatemala]

\section{NOTES}

Acknowledgments Fieldwork was supported by the Wenner-Gren Foundation, the Harry Frank Guggenheim Foundation, the Social Science Research Council, the Social Sciences and Humanities Research Council of Canada, the Open Society Foundations, the American Academy of Religion, the American Council of Learned Societies, and the Jackman Humanities Institute at the University of Toronto. Research assistants contributing to this essay included Gregory Fewster, Ayan Kassim, Basit Kareem Iqbal, Luis Pedro Jacobo Meoño Artiga, Suzanne van Geuns, and Edward Escalon. I presented a version of this material at the Jackman Humanities Institute and delivered a different version at the University of Toronto for a workshop titled "Captivity." Many thanks to my interlocutors: Jatin Dua, Susan Lepselter, Darryl Li, Juno Parreñas, Rhacel Parreñas, Andrew Shryock, Rachel Silvey, and Noah Tamarkin. Generous readings and insights also came from Bruce O'Neill, Tomas Matza, and Mayanthi Fernando. Much appreciation also to two anonymous reviewers and to the Cultural Anthropology editorial collective, especially Dominic Boyer, for their comments.

1. All interviews for this article come from fieldwork conducted in Guatemala City between 2011 and 2017 in and around Pentecostal drug rehabilitation centers. Those interviewed remain anonymous or are given pseudonyms. In some cases, details insignificant to the analysis have been changed to protect the identities of certain people. Quotations are from recorded interviews or from detailed notes. All translations are my own. All biblical quotations are taken from the New International Version. Finally, Pentecostal drug rehabilitation centers tend to be all-male institutions. Thus, the masculine pronoun is used throughout this essay to refer to captives.

2. There is an expanding social-scientific literature on compulsory drug rehabilitation centers in Latin America. See Hansen 2012, Wilkinson 2013, Garcia 2015, and O’Neill, forthcoming. See also Elovich and Drucker 2008, Wolfe and Saucier 2010, Human Rights Watch 2013, and Goldstone 2017.

3. This paragraph and the one that follows contain updated passages found in O'Neill 2017b.

4. Guatemala's prison population amounts to roughly 18,000 inmates (Walmsley 2013). This number includes pretrial detainees and remand prisoners. The Guatemalan prison system holds 1,500 of these prisoners in maximum-security facilities, while two hundred Pentecostal drug rehabilitation centers in and around Guatemala City hold about 6,000 people. 
5. This Pentecostal anthropology of body and soul returns to Platonic assumptions in ways that contrast with Michel Foucault's $(1977,30)$ notion that "the soul is the prison of the body."

6. Here, as Catherine Waldby $(2002,310)$ notes in her work on stem-cell technologies, is where we see how "the production of biovalue [gets] caught up with the production of capital value."

7. The matter of voluntary labor is most lucidly addressed ethnographically by Andrea Muehlebach $(2012,66)$, especially when she draws attention to the potential for relational labor "to bring inner disposition and intention into harmony with ameliorative public action." This dynamic between inner disposition and public action appears particularly important within these Pentecostal drug rehabilitation centers.

8. Studies of Protestant sincerity insist that words "take their meanings from intentions" (Keane 2002, 73), but here, inside these centers, sincerity is far more about bodily comportment and embodied action than speech acts.

9. João Biehl $(2005,65)$ describes a similar set of social relationships inside what he calls a zone of social abandonment: "The new pedagogical role of these abandoned men and women stems from their alleged inability to produce anything more than bodily infections, parasites, and silent suffering."

10. Guatemala's psychiatric hospital maintains a population of three hundred patients. Given that 10 to 20 percent of those held inside drug rehabilitation centers exhibit severe signs of mental illness, the number of people inside these centers with severe mental illnesses ranges anywhere from six hundred to twelve hundred people.

\section{REFERENCES}

Agamben, Giorgio

1998 Homo Sacer: Sovereign Power and Bare Life. Translated by Daniel Heller-Roazen. Stanford, Calif.: Stanford University Press. Originally published in 1995.

Allison, Anne

2013 Precarious Japan. Durham, N.C.: Duke University Press.

Anson, Angela, Brooke Ramay, Antonio Ruiz de Esparza, and Lisa Bero

2012 "Availability, Prices and Affordability of the World Health Organization's Essential Medicines for Children in Guatemala." Global Health 8, no. 22. https: / / doi.org/10.1186/1744-8603-8-22.

Aquinas, Thomas

2002 Summa Theologica. Translated by the Fathers of the English Dominican Province. Raleigh, N.C.: Hayes Barton Press. Originally published in 1485.

Augustine

1950 City of God. Translated by Marcus Dods. New York: Modern Library. Originally published in 413-426.

Biehl, João

2005 Vita: Life in a Zone of Social Abandonment. Berkeley: University of California Press. Bornstein, Erica

2012 Disquieting Gifts: Humanitarianism in New Delhi. Stanford, Calif.: Stanford University Press.

BBC News

2016 “Guatemala Ministers Arrested Over Helicopter 'Gift'.” News, June 12. http://

Butler, Judith www.bbc.com/news/world-latin-america-36508762.

2009 Frames of War: When is Life Grievable? New York: Verso.

Bynum, Caroline Walker

2001 Metamorphosis and Identity. New York: Zone Books.

Centro de Investigaciones Económicas Nacionales (CIEN)

2011 "El sistema penitenciario Guatemalteco: un diagnostico." Report. Guatemala City: Centro de Investigaciones Economicas Nacionales. 
Cohen, Jeffrey J.

2012 “The Werewolf's Indifference." Studies in the Age of Chaucer 34: 351-56. http:// doi.org/10.1353/sac.2012.0024.

Coll, Patrick G., Geraldine O'Sullivan, and Patrick J. Browne

1985 "Lycanthropy Lives On." British Journal of Psychiatry 147, no. 2: 201-202. https://doi.org/10.1192/bjp.147.2.201.

de Certeau, Michel

1984 The Practice of Everyday Life. Translated by Steven F. Rendall. Berkeley: University of California Press. Originally published in 1980.

Derrida, Jacques

2009 The Beast and the Sovereign, Volume 1. Translated by Geoffrey Bennington.

Douglas, Mary Chicago: University of Chicago Press.

1966 Purity and Danger: An Analysis of Concepts of Pollution and Taboo. New York: Routledge.

Elovich, Richard, and Ernest Drucker

2008 “On Drug Treatment and Social Control: Russian Narcology's Great Leap Backwards." Harm Reduction Journal 5, no. 23. https://doi.org/10.1186/14777517-5-23.

Fassin, Didier

2012 Humanitarian Reason: A Moral History of the Present. Translated by Rachel Gomme. Berkeley: University of California Press. Originally published in 2010.

Fielding, Amanda, and Corina Giacomello

2013 "Illicit Drugs Markets and Dimensions of Violence in Guatemala." Report. Oxford: Beckley Foundation Press. http://beckleyfoundation.org/resource/ illicit-drug-markets-and-dimensions-of-violence-in-guatemala.

Fontes, Anthony, Kevin Lewis O’Neill, and Corina Giacomello

n.d. "El impacto de las políticas de drogas en las cárceles de Guatemala." Guatemala City: Comisión Nacional para la Reforma de la Política de Drogas.

Foucault, Michel

1977 Discipline and Punish: The Birth of the Prison. Translated by Alan Sheridan. New York: Vintage. Originally published in 1975.

2007 Security, Territory, Population: Lectures at the College de France, 1977-1978. Edited by Michel Senellart and translated by Graham Burchell. New York: Picador.

Freud, Sigmund Originally published in 2004.

1996 Three Case Histories. Edited by Philip Rieff. New York: Touchstone. Originally published in 1963.

Garcia, Angela

2015 "Serenity: Violence, Inequality, and Recovery on the Edge of Mexico City." Medical Anthropology Quarterly 29, no. 4: 455-72. https://doi.org/10.1111/ maq. 12208 .

Garrard-Burnett, Virginia

2015 "A Discussion with Virginia Garrard-Burnett, Professor, University of Texas." Berkley Center for Religion, Peace and World Affairs website, September 29. https://berkleycenter.georgetown.edu/interviews/a-discussion-with-virginia-

Goffman, Erving garrard-burnett-professor-university-of-texas.

1959 The Presentation of Self in Everyday Life. New York: Random House. Originally

Goldstone, Brian published in 1956.

2017 “A Prayer's Chance: The Scandal of Mental Health in West Africa." Harper's, May. https://harpers.org/archive/2017/05/a-prayers-chance. 
Gootenberg, Paul

2008 Andean Cocaine: The Making of a Global Drug. Chapel Hill: University of North Carolina Press.

Hansen, Helena

2012 “The 'New Masculinity': Addiction Treatment as a Reconstruction of Gender in Puerto Rican Evangelist Street Ministries." Social Science and Medicine 74, no. 11: 1721-28. https: / /doi.org/10.1016/j.socscimed.2011.06.048.

Hardt, Michael, and Antonio Negri

2000 Empire. Cambridge, Mass.: Harvard University Press.

Hobbes, Thomas

1998 On the Citizen. Edited by Richard Tuck and Michael Silverthorne. New York: Human Rights Watch Cambridge University Press. Originally published in 1642.

2013 “'They Treat Us Like Animals': Mistreatment of Drug Users and 'Undesirables' in Cambodia's Drug Detention Centers.” Report. https://www.hrw.org/ report/2013/12/08/they-treat-us-animals/mistreatment-drug-users-and-

Jackson, P. M. undesirables-cambodias-drug.

1978 “Another Case of Lycanthropy." American Journal of Psychiatry 135, no. 1: 134b35. https://doi.org/10.1176/ajp.135.1.134b.

Keane, Webb

2002 “Sincerity, 'Modernity,' and the Protestants." Cultural Anthropology 17, no. 1: 65-92. https://doi.org/10.1525/can.2002.17.1.65.

Keck, Paul E., Harrison G. Pope, James I. Hudson, Susan L. McElroy, and Aaron R.

Kulick

1988 "Lycanthropy: Alive and Well in the Twentieth Century." Psychological Medicine 18, no. 1: 113-20. https://doi.org/10.1017/S003329170000194X.

Laqueur, Thomas W.

2003 Solitary Sex: A Cultural History of Masturbation. New York: Zone Books.

Li, Tania Murray

2010 "To Make Live or Let Die? Rural Dispossession and the Protection of Surplus Populations." Antipode 41, no. 1: 66-93. http://doi.org/10.1111/j.14678330.2009.00717.x.

Lohmuller, Michael

2016 “Guatemala's Government Corruption Scandals Explained." InSight Crime, June 16. https://www.insightcrime.org/news/analysis/guatemala-s-governmentcorruption-scandals-explained.

Malkki, Liisa $\mathrm{H}$.

2015 The Need to Help: The Domestic Arts of International Humanitarianism. Durham, N.C.:

Metzger, Nadine Duke University Press.

2013 "Battling Demons with Medical Authority: Werewolves, Physicians, and Rationalization." History of Psychiatry 24, no. 3: 341-55. https://doi.org/ 10.1177/0957154X13482835.

Muehlebach, Andrea

2012 The Moral Neoliberal: Welfare and Citizenship in Italy. Chicago: University of Chicago Press.

Nazianzen, Saint Gregory, and Saint Ambrose

1953 Funeral Orations. Translated by Leo P. McCauley, John J. Sullivan, Martin R. P. McGuire, and Roy J. Deferrari. Washington, DC: Catholic University of America Press.

O’Neill, Kevin Lewis

2017a “Caught on Camera." Public Culture 29, no. 3: 493-514. https://doi.org/ 10.1215/08992363-3869572. 
2017b “On Hunting.” Critical Inquiry 43, no. 3: 697-718. https://doi.org/10.1086/ 691004.

Forthcoming Hunted. Chicago: University of Chicago Press.

Otten, Charlotte F., ed.

2002 The Literary Werewolf: An Anthology. Syracuse, N.Y.: Syracuse University Press. Perez D., Sonia

2016 "Ex-Guatemalan President and VP Charged in Corruption Scheme." Associated Press, June 16. http://www.bigstory.ap.org/article/1217c688cbe44b7bb8282 678277f95e6/ex-guatemalan-president-and-vp-charged-corruption-scheme.

Petryna, Adriana

2002 Life Exposed: Biological Citizens after Chernobyl. Princeton, N.J.: Princeton University Press.

Pew Forum on Religion and Public Life

2006 "Spirit and Power: A Ten-Nation Survey of Pentecostals by the Pew Forum on Religion and Public Life." Report. Washington, DC: Pew Research Center. http://www.pewforum.org/2006/10/05/spirit-and-power.

Plato

1961 The Collected Dialogues of Plato, Including the Letters. Edited by Edith Hamilton and Huntington Cairns. Princeton, N.J.: Princeton University Press.

Povinelli, Elizabeth A.

2011 Economies of Abandonment: Social Belonging and Endurance in Late Liberalism. Durham, N.C.: Duke University Press.

Redfield, Peter

2012 "Bioexpectations: Life Technologies as Humanitarian Goods.” Public Culture 24, no. 1: 157-84. https://doi.org/10.1215/08992363-1443592.

Robbins, Joel

2013 "Beyond the Suffering Subject: Toward an Anthropology of the Good." Journal of the Royal Anthropological Institute 19, no. 3: 447-62. https://doi.org/10.1111/ 1467-9655.12044.

Rogers, Chris

2014 “Inside the 'World's Most Dangerous Hospital.” BBC News, December 5. http://www.bbc.com/news/magazine-30293880.

Rose, Nikolas

2007 The Politics of Life Itself: Biomedicine, Power, and Subjectivity in the Twenty-First Century. Princeton, N.J.: Princeton University Press.

Sarti, Carolina Escobar

2015 “Otto y el lobo.” Prensa Libre, June 20. http://www.prensalibre.com/opinion/ otto-y-el-lobo.

Sassen, Saskia

2014 Expulsions: Brutality and Complexity in the Global Economy. Cambridge, Mass.: Harvard University Press.

Scheper-Hughes, Nancy

1989 Death without Weeping: The Violence of Everyday Life in Brazil. Berkeley: University of California Press.

Shyovitz, David I.

2014 "Christians and Jews in the Twelfth-Century Werewolf Renaissance." Journal of Sridhar, Archana the History of Ideas 75, no. 4: 521-43. http://doi.org/10.1353/jhi.2014.0033.

2007 "Tax Reform and Promoting a Culture of Philanthropy: Guatemala's 'Third Sector' in an Era of Peace.” Fordham International Law Journal 31, no. 1: 186Torrano, Andrea 229. http://ir.lawnet.fordham.edu/ilj/vol31/iss1/3.

2016 "Werewolves in the Immunitary Paradigm." Philosophy Today 60, no. 1: 15373. http://doi.org/10.5840/philtoday2016113102. 
United Nations Office on Drugs and Crime (UNODC)

2012 "Transnational Organized Crime in Central America and the Caribbean: A Threat Assessment.” Report. https://www.unodc.org/toc/en/reports/TOCTA CentralAmerica-Caribbean.html.

Waldby, Catherine

2002 "Stem Cells, Tissue Cultures, and the Production of Biovalue." Health 6, no. 3: 305-323. https://doi.org/10.1177/136345930200600304.

Walmsley, Roy

2013 "World Prison Population List, Tenth Edition." London: International Center for Prison Studies. http://www.prisonstudies.org/resources/world-prisonpopulation-list-10th-edition.

Wilkinson, Annie Kathryn

2013 “Sin sanidad, no hay santidad": las practicas reparativas en Ecuador. Quito: FLACSO Ecuador.

Wolfe, Daniel, and Roxanne Saucier

2010 "In Rehabilitation's Name? Ending Institutionalized Cruelty and Degrading Treatment of People Who Use Drugs." International Journal of Drug Policy 21, no. 3: 145-48. https://doi.org/10.1016/j.drugpo.2010.01.008.

World Health Organization (WHO)

2011 Mental Health Atlas 2011. Geneva: WHO Press. http://www.who.int/ mental_health/publications/mental_health_atlas_2011/en. 